\title{
Pseudo-Enzymatic Properties of Haptoglobin:Hemoglobin Complexes
}

\author{
Giovanna De Simone, Alessandra di Masi and Paolo Ascenzi* \\ Department of Sciences, Roma Tre University, Italy
}

*Corresponding author: Paolo Ascenzi, Interdepartmental Laboratory for Electron Microscopy, Roma Tre University, Italy.

To Cite This Article: Giovanna De Simone, Alessandra di Masi and Paolo Ascenzi. Pseudo-Enzymatic Properties of Haptoglobin:Hemoglobin Complexes. Am J Biomed Sci \& Res. 2019 - 5(3). AJBSR.MS.ID.000905. DOI: 10.34297/AJBSR.2019.05.000905.

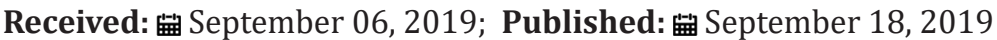

\begin{abstract}
Hemoglobin $(\mathrm{Hb})$ and free heme are physiologically released into human plasma upon hemolysis of senescent erythrocytes and erythroblasts enucleation, and pathologically because of severe hematologic diseases and blood transfusion. To inhibit the heme-based formation of free radicals, several plasma proteins have been evolved. In particular, haptoglobin ( $\mathrm{Hp}$ ) binds $\alpha \beta$ dimers of $\mathrm{Hb}$ allowing the $\mathrm{Hb}$ removal via the reticuloendothelial system and the CD163 receptor-mediated endocytosis in hepatocytes, Kupffer cells, and tissue macrophages. In turn, the Hp:Hb complexes facilitate heme-based detoxification of $\mathrm{NO}$ and peroxynitrite and display $\mathrm{NO}_{2}^{-}$- reductase activity opening new avenues in removing reactive nitrogen species in plasma. The correlation between $\mathrm{Hp}$ glycosylation, the stability of the $\mathrm{Hp}: \mathrm{Hb}$ complexes and pathological conditions (i.e., cancer) has been observed.

Keywords: haptoglobin 1-1:hemoglobin complex; haptoglobin 2-2:hemoglobin complex; pseudo-enzymatic properties.

Abbreviations: CCP: Complement control protein domain; Hb: Human hemoglobin; $\mathrm{Hb}(\mathrm{II})$ : Ferrous Hb; $\mathrm{Hb}(\mathrm{II})-\mathrm{NO}$ : $\mathrm{Nitrosylated} \mathrm{Hb}(\mathrm{II}) ; \mathrm{Hb}(\mathrm{II})-\mathrm{O}_{2}$ : Ferrous oxygenated Hb; Hb(III): Ferric Hb; Hp: Human haptoglobin; Hp:Hb: Hp:Hb complex; Hp:Hb(II): Ferrous Hp:Hb complex; Hp:Hb(II)-NO: Nitrosylated Hp:Hb(II)complex; Hp:Hb(II)- $\mathrm{O}_{2}$ : Ferrous oxygenated Hp:Hb complex; Hp:Hb(III): Ferric Hp:Hb complex; Hp:Hb(III)-NO: Nitrosylated $\mathrm{Hp}: \mathrm{Hb}(\mathrm{III})$ complex; Hp:Hb(III)-OONO־: Peroxynitrite-bound Hp:Hb(III); Hp1-1: Phenotype 1-1 of Hp; Hp1-1:Hb: Hp1-1:Hb complex; Hp1-1:Hb(II): Ferrous Hp1-1:Hb complex; Hp1-1:Hb(III): Ferric Hp1-1:Hb complex; Hp2-2: Phenotype 2-2 of Hp; Hp2-2:Hb: Hp2-2:Hb complex; Hp2-2:Hb(II): Ferrous Hp2-2:Hb complex; Hp2-2:Hb(III): Ferric Hp2-2:Hb complex; RBC: Red blood cell; SP: Serine protease-like domain
\end{abstract}

\section{Hemoglobin}

The deleterious effects of oxidative and nitrosative stress, such as damage to cellular proteins, DNA, and lipids, are well characterized. Red blood cell (RBC) homeostasis is an excellent example of redox balance: erythroid progenitors accumulate hemoglobin $(\mathrm{Hb})$ during development and continuously transport large amounts of oxygen over the course of their lifespan. Moreover, RBCs represent an important inter-organ communication system with a key role in the control of systemic nitric oxide metabolism. To inhibit the heme-based formation of free radicals, several plasma proteins have been evolved [1,2].

$\mathrm{Hb}$ is physiologically released into human plasma upon hemolysis of senescent RBCs and erythroblasts enucleation, and pathologically because of severe hematologic diseases and blood transfusion [3-7]. Since plasmatic $\mathrm{Hb}$ brings about the formation of free radicals, living organisms have evolved efficient mechanisms to trap extra-erythrocytic Hb scavenging [5,6,8-10]. Haptoglobin (Hp) traps $\alpha \beta$ dimers of $H b$ leading to very stable non-covalent complexes, which allow the removal of $\mathrm{Hb}$ via the reticuloendothelial system and the CD163 receptor-mediated endocytosis in hepatocytes, Kupffer cells, and tissue macrophages [11-14]. Hp binding to
$\mathrm{Hb}(\mathrm{i})$ prevents $\mathrm{Hb}$ entry into the endothelium, (ii) affects heme redox properties, (iii) inhibits the heme dissociation, and (iv) protects several $\mathrm{Hb}$ residues at the $\mathrm{Hp}: \mathrm{Hb}$ interface from oxidative modifications [15-18].

\section{Haptoglobin}

The human Hp gene consists of three structural alleles: $H p 1 F$, $H p 1 S$, and $H p 2$. The products of the $H p 1 F$ and $H p 1 S$ alleles differ by only one amino acid, whereas the $H p 2$ allele is the result of a fusion of the $H p 1 F$ and $H p 1 S$ alleles giving rise to a longer chain. Human $\mathrm{Hp}$ is a $90 \mathrm{kDa}$ single polypeptide chain constituted by a complement control protein (CCP) domain and a serine protease- (SP-) like domain. The SP-like domain is proteolytically cleaved into an $\alpha$ and a $\beta$ chain covalently linked by a disulfide bond. $H p 1$ consists of a single CCP domain while Hp2 contains two CCP domains [19]. The CCP domains are responsible for a head-to-head dimerization of $\mathrm{Hp}$ through an unusual $\beta$ strands swap and intermolecular disulfide bonds. The occurrence of the $\mathrm{Hp} 1$ and $\mathrm{Hp} 2$ alleles in humans gives rise to Hp1-1 dimers (covalently linked by Cys15 residues), Hp1-2 hetero-oligomers and Hp2-2 oligomers (covalently linked by Cys15 and Cys74 residues) [19]. Each Hp $\beta$ chain of the SP-like domain 
binds the $\alpha \beta$ dimer of $\mathrm{Hb}$ in a 1:1 stoichiometry making extensive contacts that mask the $\mathrm{Hb}$ dimer-dimer interface. This is at the roots of the high binding affinity between the two proteins and of the ability of $\mathrm{Hp}$ to bind only the dimeric form of $\mathrm{Hb}$ (Figure 1) [20$22]$.

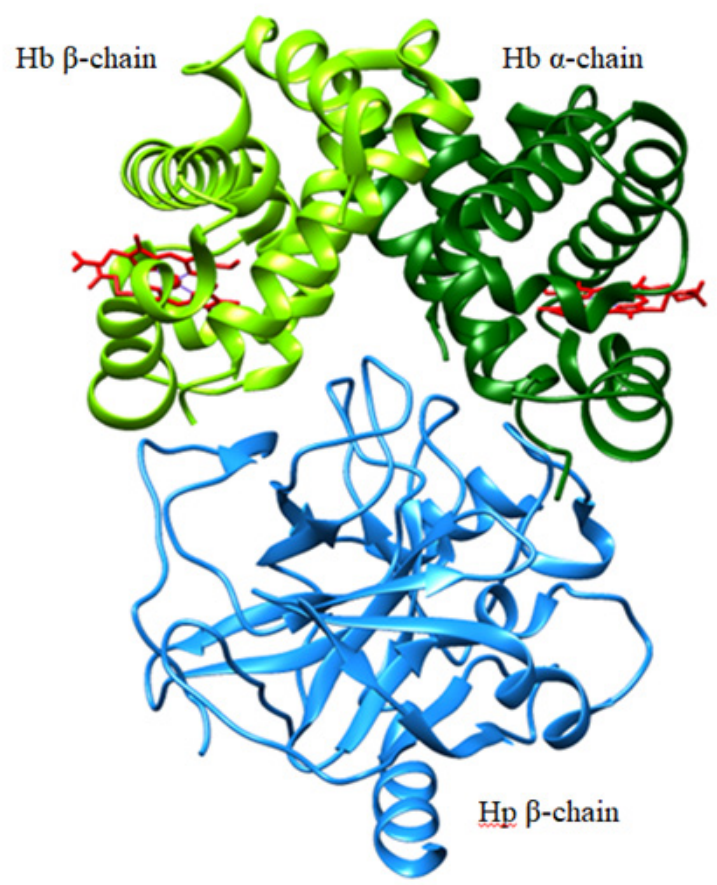

Figure 1: Three-dimensional structure of the human Hp:Hb (PDB ID: 4XOL) [20]. The $\beta$ chain of $\mathrm{Hp}$ is rendered in blue, the $\alpha$ and $\beta$ chains of Hb are rendered in dark and light green, and the hemes are rendered in red. The picture has been drawn with the UCSF-ChimeraX package [21]

\section{Haptoglobin:hemoglobin complexes}

$\mathrm{Hp}: \mathrm{Hb}$ complexes (i.e., Hp1-1:Hb and Hp2-2:Hb) (i) react with $\mathrm{O}_{2}$, CO, NO, cyanide, fluoride, azide, thiocyanate, and imidazole [2329], (ii) undergo reductive nitrosylation [26], (iii) facilitate the heme-based detoxification of $\mathrm{NO}$ and peroxynitrite [15,30], and (iv) catalyze the $\mathrm{NO}_{2}{ }^{-}$conversion to NO (Table 1) [31-37]. Noteworthy, the ligand binding and reactivity properties $\mathrm{Hp} 1-1: \mathrm{Hb}$ and Hp2$2: \mathrm{Hb}$ are reminiscent those of the $\mathrm{R}$ quaternary state of the $\mathrm{Hb}$ tetramer [26-31,38]. The inspection of the global pathway of $\mathrm{Hp}: \mathrm{Hb}$ reactivity (Fig. 2) allows the following considerations.

\begin{tabular}{|c|c|c|c|c|}
\hline Reaction & Heme-protein & Kineti & odynamic Param & \\
\hline \multirow{8}{*}{$\mathrm{O}_{2}$ binding $^{\mathrm{a}}$} & \multirow{2}{*}{$\mathrm{Hb}$ (II) T-state } & $\mathrm{k}_{\mathrm{on} 1}=1.1 \times 10^{7} \mathrm{M}^{-1} \mathrm{~s}^{-1}$ & $\mathrm{k}_{\mathrm{off} 1}=3.7 \times 10^{3} \mathrm{~s}^{-1}$ & $\mathrm{~K}_{1}=3.4 \times 10^{-4} \mathrm{M}$ \\
\hline & & $\mathrm{k}_{\mathrm{on} 2}=5.0 \times 10^{6} \mathrm{M}^{-1} \mathrm{~s}^{-1}$ & $\mathrm{k}_{\mathrm{off} 2}=1.8 \times 10^{3} \mathrm{~s}^{-1}$ & $\mathrm{~K}_{2}=3.6 \times 10^{-4} \mathrm{M}$ \\
\hline & \multirow{2}{*}{$\mathrm{Hb}$ (II) R-state } & $\mathrm{k}_{\mathrm{on} 1}=7.6 \times 10^{7} \mathrm{M}^{-1} \mathrm{~s}^{-1}$ & $\mathrm{k}_{\text {offi }}=3.2 \times 10^{1} \mathrm{~s}^{-1}$ & $\mathrm{~K}_{1}=4.2 \times 10^{-7} \mathrm{M}$ \\
\hline & & $\mathrm{k}_{\mathrm{on} 2}=3.6 \times 10^{7} \mathrm{M}^{-1} \mathrm{~s}^{-1}$ & $\mathrm{k}_{\mathrm{off} 2}=1.6 \times 10^{1} \mathrm{~s}^{-1}$ & $\mathrm{~K}_{2}=4.4 \times 10^{-7} \mathrm{M}$ \\
\hline & \multirow[t]{2}{*}{ Hp1-1: Hb (II) } & $\mathrm{k}_{\mathrm{on} 1}=4.5 \times 10^{7} \mathrm{M}^{-1} \mathrm{~s}^{-1}$ & $\mathrm{k}_{\mathrm{off} 1}=2.8 \times 10^{1} \mathrm{~s}^{-1}$ & $\mathrm{~K}_{1}=6.2 \times 10^{-7} \mathrm{M}$ \\
\hline & & $\mathrm{k}_{\mathrm{on} 2}=4.5 \times 10^{7} \mathrm{M}^{-1} \mathrm{~s}^{-1}$ & $\mathrm{k}_{\mathrm{off} 2}=1.6 \times 10^{1} \mathrm{~s}^{-1}$ & $\mathrm{~K}_{2}=3.6 \times 10^{-7} \mathrm{M}$ \\
\hline & \multirow[t]{2}{*}{ Hp2-2: Hb (II) } & & $\mathrm{k}_{\mathrm{off} 1}=2.7 \times 10^{1} \mathrm{~s}^{-1}$ & \\
\hline & & & $\mathrm{k}_{\mathrm{off2}}=1.4 \times 10^{1} \mathrm{~s}^{-1}$ & \\
\hline \multirow{4}{*}{ NO binding ${ }^{\mathrm{b}}$} & $\mathrm{Hb}$ (II) T-state & $\mathrm{k}_{\mathrm{on}}=2.4 \times 10^{7} \mathrm{M}^{-1} \mathrm{~s}^{-1}$ & $\mathrm{k}_{\mathrm{off}} \sim 1 \times 10^{-3} \mathrm{~s}^{-1}$ & $\mathrm{~K} \sim 4 \times 10^{-11} \mathrm{M}$ \\
\hline & $\mathrm{Hb}$ (II) R-state & $\mathrm{k}_{\mathrm{on}}=2.4 \times 10^{7} \mathrm{M}^{-1} \mathrm{~s}^{-1}$ & $\mathrm{k}_{\mathrm{off}} \sim 1 \times 10^{-5} \mathrm{~s}^{-1}$ & $\mathrm{~K} \sim 4 \times 10^{-13} \mathrm{M}$ \\
\hline & Hp1-1: Hb (II) & $\mathrm{k}_{\mathrm{on}}=1.1 \times 10^{7} \mathrm{M}^{-1} \mathrm{~s}^{-1}$ & $\mathrm{k}_{\mathrm{off}}<2.0 \times 10^{-4} \mathrm{~s}^{-1}$ & $\mathrm{~K}<2 \times 10^{-11} \mathrm{M}$ \\
\hline & Hp2-2: Hb (II) & $\mathrm{k}_{\mathrm{on}}=9.3 \times 10^{6} \mathrm{M}^{-1} \mathrm{~s}^{-1}$ & $\mathrm{k}_{\text {off }}<2.0 \times 10^{-4} \mathrm{~s}^{-1}$ & $\mathrm{~K}<2 \times 10^{-11} \mathrm{M}$ \\
\hline \multirow{3}{*}{ NO binding ${ }^{c}$} & $\mathrm{Hb}(\mathrm{III})$ & & & $\mathrm{K}=8.3 \times 10^{-5} \mathrm{M}$ \\
\hline & Hp1-1: Hb (III) & & & $\mathrm{K}=1.4 \times 10^{-4} \mathrm{M}$ \\
\hline & Hp2-2: Hb (III) & & & $\mathrm{K}=2.1 \times 10^{-4} \mathrm{M}$ \\
\hline
\end{tabular}




\begin{tabular}{|c|c|c|c|}
\hline \multirow{3}{*}{ NO detoxification ${ }^{\mathrm{d}}$} & $\mathrm{Hb}(\mathrm{II})-\mathrm{O}_{2}$ & $\mathrm{k}_{\mathrm{on}}=6.0 \times 10^{6} \mathrm{M}^{-1} \mathrm{~s}^{-1}$ & \\
\hline & Hp1-1: $\mathrm{Hb}(\mathrm{II})-\mathrm{O}_{2}$ & $\mathrm{k}_{\mathrm{on}}=6.1 \times 10^{6} \mathrm{M}^{-1} \mathrm{~s}^{-1}$ & \\
\hline & $\mathrm{Hp} 2-2: \mathrm{Hb}(\mathrm{II})-\mathrm{O}_{2}$ & $\mathrm{k}_{\mathrm{on}}=6.0 \times 10^{6} \mathrm{M}^{-1} \mathrm{~s}^{-1}$ & \\
\hline \multirow{3}{*}{$\begin{array}{l}\text { Peroxynitrite detoxifica- } \\
\text { tion }^{\mathrm{e}}\end{array}$} & $\mathrm{Hb}(\mathrm{III})$ & $\mathrm{k}_{\mathrm{on}}=1.2 \times 10^{4} \mathrm{M}^{-1} \mathrm{~s}^{-1}$ & \\
\hline & Hp1-1: Hb (III) & $\mathrm{k}_{\mathrm{on}}=1.7 \times 10^{4} \mathrm{M}^{-1} \mathrm{~s}^{-1}$ & \\
\hline & Hp2-2: Hb (III) & $\mathrm{k}_{\mathrm{on}}=1.6 \times 10^{4} \mathrm{M}^{-1} \mathrm{~s}^{-1}$ & \\
\hline \multirow{4}{*}{ Nitrite reduction ${ }^{\mathrm{f}}$} & Hb (II) T-state & $\mathrm{k}_{\mathrm{on}}=1.2 \times 10^{-1} \mathrm{M}^{-1} \mathrm{~s}^{-1}$ & \\
\hline & $\mathrm{Hb}$ (II) R-state & $\mathrm{k}_{\mathrm{on}}=6.0 \mathrm{M}^{-1} \mathrm{~s}^{-1}$ & \\
\hline & Hp1-1: Hb (II) & $\mathrm{k}_{\mathrm{on}}=7.3 \mathrm{M}^{-1} \mathrm{~s}^{-1}$ & \\
\hline & Hp2-2: Hb (II) & $\mathrm{k}_{\mathrm{on}}=1.2 \times 10^{1} \mathrm{M}^{-1} \mathrm{~s}^{-1}$ & \\
\hline \multirow{3}{*}{ Reductive nitrosylation ${ }^{c}$} & $\mathrm{Hb}(\mathrm{III})$ & $\mathrm{k}_{\mathrm{OH}-}=3.2 \times 10^{3} \mathrm{M}^{-1} \mathrm{~s}^{-1}$ & $\mathrm{k}_{\mathrm{H} 2 \mathrm{O}}=1.1 \times 10^{-3} \mathrm{~s}^{-1}$ \\
\hline & Hp1-1: Hb (III) & $\mathrm{k}_{\mathrm{OH}-}=4.9 \times 10^{3} \mathrm{M}^{-1} \mathrm{~s}^{-1}$ & $\mathrm{k}_{\mathrm{H} 2 \mathrm{O}}=2.6 \times 10^{-3} \mathrm{~s}^{-1}$ \\
\hline & Hp2-2: Hb (III) & $\mathrm{k}_{\mathrm{OH}-}=6.7 \times 10^{3} \mathrm{M}^{-1} \mathrm{~s}^{-1}$ & $\mathrm{k}_{\mathrm{H} 2 \mathrm{O}}=2.6 \times 10^{-3} \mathrm{~s}^{-1}$ \\
\hline \multicolumn{4}{|c|}{ 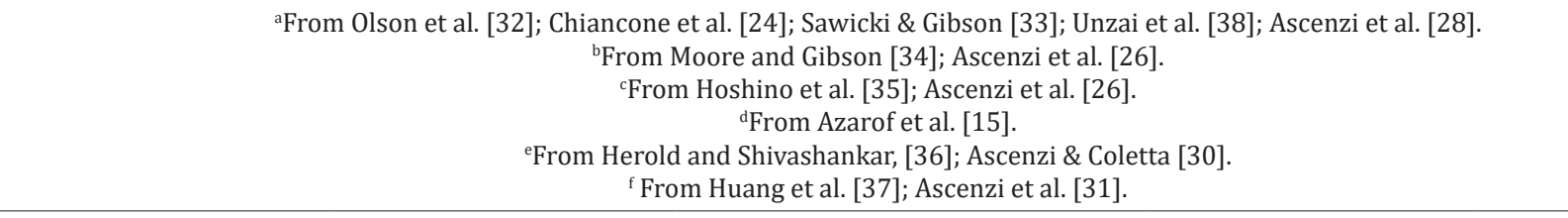 } \\
\hline
\end{tabular}

1) Ferrous oxygenated $\mathrm{Hp}: \mathrm{Hb}\left(\mathrm{Hp}: \mathrm{Hb}(\mathrm{II})-\mathrm{O}_{2}\right.$ ) catalyzes $\mathrm{NO}$ detoxification reacting very rapidly with NO; this reaction leads to the formation of the ferric derivative $\mathrm{Hp}: \mathrm{Hb}(\mathrm{III})$ by way of the transient peroxynitrite-bound species (Hp:Hb(III)-OONO-) which release vary rapidly $\mathrm{NO}_{3}{ }^{-}(\sim 90 \%)$ and $\mathrm{NO}_{2}{ }^{-}(\sim 10 \%)[15]$.

2) (ii) $\mathrm{O}_{2}$ may facilitate also the detoxification of ferrous nitrosylated $\mathrm{Hp}: \mathrm{Hb}$ (Hp:Hb(II)-NO) as reported for ferrous nitrosylated $\mathrm{Hb}$ ( $\mathrm{Hb}(\mathrm{II})-\mathrm{NO}$ ) [39]. The reaction of $\mathrm{Hb}(\mathrm{II})-\mathrm{NO}$ with $\mathrm{O}_{2}$ is limited from the NO dissociation and the transient formation of the $\mathrm{Hb}(\mathrm{II})-\mathrm{O}_{2}$ species. In turn, $\mathrm{Hb}(\mathrm{II})-\mathrm{O}_{2}$ reacts with $\mathrm{NO}$ leading to the formation of ferric $\mathrm{Hb}(\mathrm{Hb}(\mathrm{III})), \mathrm{NO}_{3}{ }^{-}$and $\mathrm{NO}_{2}{ }^{-}$by way of the $\mathrm{Hb}(\mathrm{III})-00 \mathrm{NO}^{-}$derivative.

3) (iii) The $\mathrm{Hp}: \mathrm{Hb}(\mathrm{III})$ species facilitate peroxynitrite detoxification leading to the formation of $\mathrm{NO}_{3}{ }^{-}(\sim 90 \%)$ and $\mathrm{NO}_{2}{ }^{-}$ $(\sim 10 \%)$ by way of the transient $\mathrm{Hp}: \mathrm{Hb}(\mathrm{III})-\mathrm{OONO}^{-}$species.

4) (iv) The Hp:Hb(III) complexes react with NO leading to the formation of the very stable $\mathrm{Hp}: \mathrm{Hb}(\mathrm{II})-\mathrm{NO}$ complex. This process is characterized by the formation of the nitrosylated $\mathrm{Hp}: \mathrm{Hb}$ (III) derivative (Hp:Hb(III)-NO) that is in equilibrium with the $\mathrm{Hp}: \mathrm{Hb}(\mathrm{II})-\mathrm{NO}^{+}$species; under alkaline conditions, $\mathrm{Hp}: \mathrm{Hb}(\mathrm{II})-$ $\mathrm{NO}^{+}$converts to $\mathrm{Hp}: \mathrm{Hb}(\mathrm{II})-\mathrm{NO}[26]$.

5) Under reductive conditions, ferrous $\mathrm{Hp}: \mathrm{Hb}(\mathrm{Hp}: \mathrm{Hb}(\mathrm{II})$ ) traps $\mathrm{NO}_{2}^{-}$leading to the formation of the highly stable $\mathrm{Hp}: \mathrm{Hb}(\mathrm{II})$ NO derivative. This reaction is characterized from the transient formation of $\mathrm{Hp}: \mathrm{Hb}(\mathrm{III})$ and NO species [30].

\section{Clinical implications}

Considering that about $10 \%$ of senescent RBCs undergo hemolysis in plasma, the $\mathrm{Hp}: \mathrm{Hb}$-based reactions shown in Figure 2 may participate to the detoxification of reactive nitrogen species present in plasma that are implicated in atherosclerosis, inflammation, and neurodegenerative disorders [40-53]. Indeed, the ligand binding and reactivity properties of extraerythrocytic $\mathrm{Hp}: \mathrm{Hb}$ are not limited from membrane diffusion of NO, peroxynitrite, and $\mathrm{NO}_{2}{ }^{-}$in RBCs. Indeed, this represents the prerequisite for intra-erythrocytic $\mathrm{Hb}$-based catalysis. Glycoslation has been reported to play a clinical role on Hp actions [54]. In fact, the Hp $\beta$ chain contains four N-glycosylable sites (i.e., Asn184, Asn207, Asn211, and Asn241) that can be linked to either sialylated or fucosylated glycans $[55,56]$. However, in the Hp2-2 complex the steric hindrance of the neighboring monomers prevents or reduces the normal glycan incorporations [57]. The affinity of $\mathrm{Hb}$ for $\mathrm{Hp}$ is affected by Hp glycosylation, and the Hb:Hp glycosylated complex is more thermostable compared to either the $\mathrm{Hb}: \mathrm{Hp}$ deglycosylated complex or to the free $\mathrm{Hb}$ and $\mathrm{Hp}$ molecules [56].

This suggests a potential effect of $\mathrm{Hp}$ glycosylation in the intrinsic physical and redox properties of $\mathrm{Hp}$, with possible systemic effects on the circulation and the clearance times $[54,56]$. Several clinical studies hypothesized a correlation of Hp glycosylation with different diseases. Glycosylation of $\mathrm{Hp}$ have been associated with infectious sera of patients [58] but also with many types of cancers, including pancreatic [59-61], hepatic [62,63], prostate [64], lung [65,66], ovarian [67], colon [68], and gastric cancer [69]. Although differences in Hp glycosylation have been reported, methodological hitches in characterizing glycosylated complexes preclude interpretations. Overall, based on the reported aberrant glycan patterns, Hp could possibly become a potential biomarker for risk prediction and identification of some disorders, eventually being combined with other biomarkers in order to increase the diagnostic efficiency of specific diseases [Ratanasopa et al., 2013; Zhang et al., 2016]. Indeed, it has been reported that 
the fucosylated $\mathrm{Hp}$ in combination with the CA125 biomarker (also known as mucin 16, the only clinically reliable diagnostic marker for ovarian cancer [70]) could be used to discriminate between healthy condition, early-stage ovarian cancer, and stage III ovarian cancer $[54,63,65,71]$.

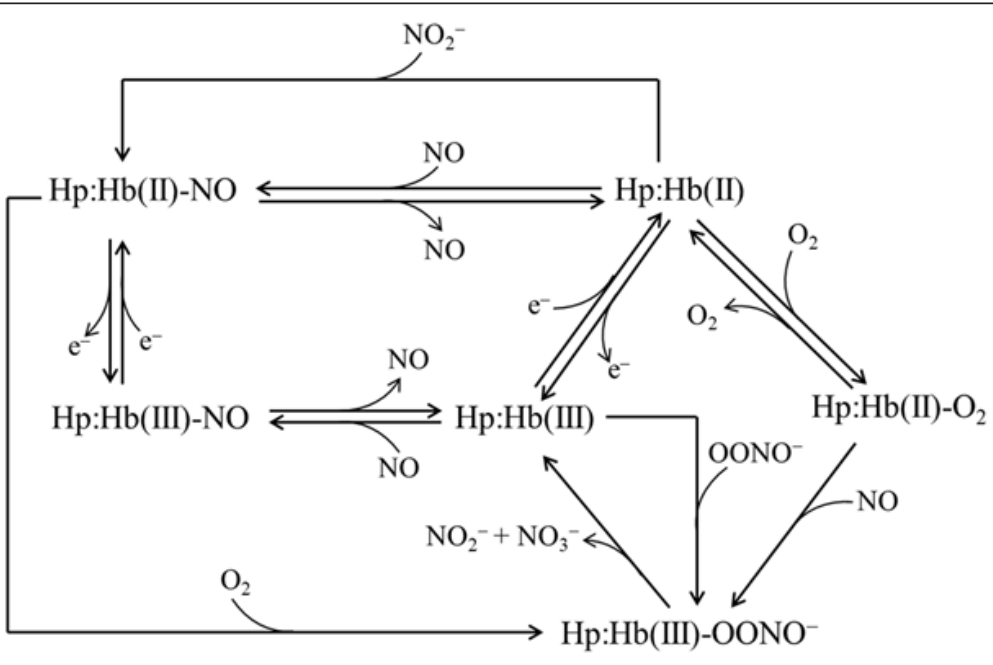

Figure 2: Global pathway of human $\mathrm{Hp}$ : $\mathrm{Hb}$ reactivity.

It remains to be determined if variations in the glycan composition of Hp play a role also in the onset of some diseases, possibly perturbing the protective role of $\mathrm{Hp}$ or reflecting a variation of the glycosyl transferease expression systems. The development of novel diagnostic technologies will allow to better determine $\mathrm{Hp}$ glycosylation status and the specific glycosylated sites; in turn, this information will be fundamental for an unequivocal correlation between Hp glycosylation and a pathological condition and for their accurate diagnosis.

\section{Acknowledgment}

The grant of Dipartimenti di Eccellenza, MIUR (Legge 232/2016, Articolo 1, Comma 314-337) is gratefully acknowledged.

\section{References}

1. Weidinger AV, Kozlov (2015) Biological activities of reactive oxygen and nitrogen species: oxidative stress versus signal transduction. Biomolecules 5: 472-484.

2. V Kuhn, L Diederich, TCS Keller TCS 4th, CM Kramer, W Lückstädt, C. Panknin, T. Suvorava, B.E. Isakson, M. Kelm, M.M Cortese-Krott, et al. (2017) Red blood cell function and dysfunction: redox regulation, nitric oxide metabolism, anemia. Antioxid Redox Signal. 26: 718-742.

3. U Muller-Eberhard, J Javid, HH Liem, A Hanstein, M Hanna (1968) Plasma concentrations of hemopexin, haptoglobin and heme in patients with various hemolytic diseases. Blood 32: 811-815.

4. HF Bunn, BG Forget (1986) Hemoglobin: Molecular, Genetic and Clinical Aspects, Saunders. Philadelphia.

5. P Ascenzi, A Bocedi, P Visca, F Altruda, E Tolosano, et al (2005) Hemoglobin and heme scavenging. IUBMB Life 57(11): 749-759.

6. M Fasano, S Curry, SE Terreno, M Galliano, G Fanali, et al (2005) The extraordinary ligand binding properties of human serum albumin. IUBMB Life 57(12): 787-796.

7. AI Alayash, CB Andersen, SK Moestrup, L Bülow (2013) Haptoglobin: the hemoglobin detoxifier in plasma. Trends Biotechnol. 3(1): 2-3.

8. AI Alayash (2004) Oxygen therapeutics: can we tame haemoglobin? Nat. Rev. Drug. Discov 3(2): 152-159.
9. DJ Schaer, F Vinchi, G Ingoglia, E Tolosano, PW Buehler (2014) Haptoglobin, hemopexin, and related defense pathways-basic science, clinical perspectives, and drug development. Front Physiol 5: 415.

10. M MacKellar, DJ Vigerust (2016) Role of haptoglobin in health and disease: a focus on diabetes. Clin. Diabetes 34(3): 148-157.

11. M Kristiansen, JH Graversen, C Jacobsen, O Sonne, HJ Hoffman, et al (2001) Identification of the haemoglobin scavenger receptor. Nature 409 (6817): 198-201.

12. PW Buehler, B Abraham, $\mathrm{F}$ Vallelian, $\mathrm{C}$ Linnemayr, CP Pereira, et al. (2009) Haptoglobin preserves the CD163 hemoglobin scavenger pathway by shielding hemoglobin from peroxidative modificatio. Blood 113(11): 2578-2586.

13. T Kaempfer, E Duerst, P Gehrig, B Roschitzki, D Rutishauser, et al. (2011) Extracellular hemoglobin polarizes the macrophage proteome toward Hb-clearance, enhanced antioxidant capacity and suppressed HLA class 2 expression. J Proteome Res 10(5): 2397-2408.

14. CBF Andersen, K Stødkilde, KL Sæderup, A Kuhlee, S Raunser, et al (2017) Haptoglobin. Antioxid Redox Signal 26(14): 814-831.

15. Azarov, X He, A Jeffers, S Basu, B Ucer, et al. (2008) Rate of nitric oxide scavenging by hemoglobin bound to haptoglobin. Nitric Oxide 18(4): 296-302.

16. CB Andersen, M Torvund-Jensen, MJ Nielsen, CL de Oliveira, HP Hersleth, et al (2012) Structure of the haptoglobin-haemoglobin complex. Nature 489: 456-459.

17. JH Baek, FD’Agnillo, F Vallelian, CP Pereira, MC Williams, et al. (2012) Hemoglobin-driven pathophysiology is an in vivo consequence of the red blood cell storage lesion that can be attenuated in guinea pigs by haptoglobin therapy. J Clin Invest 122(4): 1444-1458.

18. TL Mollan, Y Jia, S Banerjee, G Wu, RT Kreulen, et al. (2014) Redox properties of human hemoglobin in complex with fractionated dimeric and polymeric human haptoglobin. Free Radic Biol Med 69: 265-277.

19. F Polticelli, A Bocedi, G Minervini, P Ascenzi (2008) Human haptoglobin structure and function - a molecular modelling study. FEBS J. 275(22): 5648-5656.

20. H Lane-Serff, P MacGregor, ED Lowe, M Carrington, MK Higgins (2014) Structural basis for ligand and innate immunity factor uptake by the trypanosome haptoglobin-haemoglobin receptor. Elife 3: e05553.

21. TD Goddard, CC Huang, EC Meng, EF Pettersen, GS Couch, et al. (2018) 
UCSF ChimeraX: meeting modern challenges in visualization and analysis. Protein Sci 27(1): 14-25.

22. K Stødkilde, M Torvund-Jensen, SK Moestrup, CB Andersen (2014) Structural basis for trypanosomal haem acquisition and susceptibility to the host innate immune system. Nat Commun 5: 5487.

23. RL Nagel, QH Gibson (1966) Kinetics of the reaction of carbon monoxide with the hemoglobin-haptoglobin complex. J Mol Biol 22(2): 249-255.

24. E Chiancone, E Antonini, M Brunori, A Alfsen, F Lavialle (1973) Kinetics of the reaction between oxygen and haemoglobin bound to haptoglobin. Biochem J 133(1): 205-207.

25. E Antonini, M Brunori, Hemoglobin and myoglobin in their reactions with ligands. North Holland Publishing Co, Amsterdam, 1971.

26. P Ascenzi, M Coletta (2018) Peroxynitrite detoxification by human haptoglobin:hemoglobin complexes: a comparative study. J Phys Chem B 122(49): 11100-11107.

27. P Ascenzi, A di Masi, G De Simone, M Gioia, M Coletta (2019) Fluoride and azide binding to ferric human hemoglobin:haptoglobin complexes highlights the ligand-dependent inequivalence of the $\alpha$ and $\beta$ hemoglobin chains. J Biol. Inorg Chem 24(2): 247-255.

28. P Ascenzi, F Polticelli, M Coletta, (2019) Oxygen dissociation from ferrous oxygenated human hemoglobin:haptoglobin complexes confirms that in the R-state $\alpha$ and $\beta$ chains are functionally heterogeneous. Sci Rep 9(1): 6780

29. P Ascenzi, G de Simone, C Ciaccio, M Coletta (2019) Ligand-dependent inequivalence of the $\alpha$ and $\beta$ subunits of ferric human hemoglobin bound to haptoglobin. J Inorg. Biochem in press.

30. P Ascenzi, GR Tundo, M Coletta (2018) The nitrite reductase activity of ferrous human hemoglobin:haptoglobin 1-1 and 2-2 complexes. J Inorg Biochem 187: 116-122.

31. P Ascenzi, G De Simone, F Polticelli, M Gioia, M Coletta (2018) Reductive nitrosylation of ferric human hemoglobin bound to human haptoglobin 1-1 and 2-2. J Biol Inorg Chem 23(3): 437-445.

32. JS Olson, ME Andersen, QH Gibson (1971) The dissociation of the first oxygen molecule from some mammalian oxyhemoglobins. J Biol Chem 246: 5919-5923.

33. CA Sawicki, QH Gibson (1977) Properties of the T state of human oxyhemoglobin studies by laser photolysis. J Biol Chem 252: 7538-7547.

34. EG Moore, QH Gibson (1976) Cooperativity in the dissociation of nitric oxide from hemoglobin. J Biol Chem 251:2788-2794.

35. M Hoshino, M Maeda, R Konishi, H Seki, PC Ford (1996) Studies on the reaction mechanism for reductive nitrosylation of ferrihemoproteins in buffer solutions. J Am Chem Soc 118: 5702-5707.

36. S Herold, K Shivashankar (2003) Metmyoglobin and methemoglobin catalyze the isomerization of peroxynitrite to nitrate, Biochemistry 42(47): 14036-14046.

37. Z Huang, S Shiva, DB Kim-Shapiro, RP Patel, LA Ringwood, et al. (2005) Enzymatic function of hemoglobin as a nitrite reductase that produces NO under allosteric control. J Clin Invest 115(8): 2099-2107.

38. S Unzai, R Eich, N Shibayama, JS Olson, H Morimoto (1998) Rate constants for $\mathrm{O}_{2}$ and $\mathrm{CO}$ binding to the $\alpha$ and $\beta$ subunits within the R and T states of human hemoglobin. J Biol Chem 273: 23150-23159.

39. S Herold S, G Röck (2005) Mechanistic studies of the oxygen-mediated oxidation of nitrosyl hemoglobin. Biochemistry 44: 6223-6231.

40. JS Beckman, WH Koppenol (1996) Nitric oxide, superoxide, and peroxynitrite: the good, the bad, and ugly, Am. J. Physiol. 271: C1424-C1437.

41. C Ducrocq, B Blanchard, B Pignatelli, H Oshima (1999) Peroxynitrite: an endogenous oxidizing and nitrating agent. Cell Mol Life Sci 55: 10681077.
42. LJ Ignarro (2002) Nitric oxide as a unique signaling molecule in the vascular system: a historical overview. J Physiol Pharmacol 53: 503-514.

43. E Clementi, E Nisoli (2005) Nitric oxide and mitochondrial biogenesis: a key to long-term regulation of cellular metabolism, Comp. Biochem. Physiol A Mol Integr Physiol 142(2): 102-110.

44. Denicola, R Radi (2005) Peroxynitrite and drug-dependent toxicity. Toxicology 208(2): 273-288.

45. P Pacher, JS Beckman, L Liaudet (2007) Nitric oxide and peroxynitrite in health and disease. Physiol Rev 87(1): 315-424.

46. S Goldstein, G Merényi (2008) The chemistry of peroxynitrite: implications for biological activity, Methods Enzymol. 436: 49-61.

47. P Ascenzi, A di Masi, C Sciorati, E Clementi (2010) Peroxynitrite - An ugly biofactor? Bio Factors 36(4): 264-273.

48. S Carballal, S Bartesaghi, R Radi (2014) Kinetic and mechanistic considerations to assess the biological fate of peroxynitrite, Biochim. Biophys. Acta 1840(2): 768-780.

49. R Ahmad, A Hussain, H Ahsan (2019) Peroxynitrite: cellular pathology and implications in autoimmunity. J Immunoassay Immunochem 40(2): 123-138.

50. MM Essa, M Moghadas, T Ba-Omar, M Walid Qoronfleh, GJ Guillemin, et al. (2019) Protective effects of antioxidants in Huntington's disease: an extensive review. Neurotox Res. 35(3): 739-774.

51. V Greco, P Longone, A Spalloni, L Pieroni, A Urbani (2019) Crosstalk between oxidative stress and mitochondrial damage: focus on amyotrophic lateral sclerosis. Adv Exp Med Biol 1158: 71-82.

52. Rizor, E Pajarillo, J Johnson, M Aschner, E Lee (2019) Astrocytic oxidative/nitrosative stress contributes to Parkinson's disease pathogenesis: the dual role of reactive astrocytes, Antioxidants (Basel) 8(8): E265.

53. J Tejero, S Shiva, MT Gladwin (2019) Sources of vascular nitric oxide and reactive oxygen species and their regulation. Physiol Rev 99(1): 311379.

54. S Zhang, S Shang, W Li, X Qin, Y Liu (2016) Insights on N-glycosylation of human haptoglobin and its association with cancers, Glycobiology 26(7): 684-692.

55. HY Tsai, K Boonyapranai, S Sriyam, CJ Yu, SW Wu, K.H. Khoo, S. Phutrakul S.T. Chen, et al. (2011) Glycoproteomics analysis to identify a glycoform on haptoglobin associated with lung cancer, Proteomics 11(11): 2162 2170.

56. K Ratanasopa, S Chakane, M Ilyas, C Nantasenamat, L Bulow, (2013) Trapping of human hemoglobin by haptoglobin: molecular mechanisms and clinical applications. Antioxid Redox Signal 18(17): 2364-2374.

57. K Boonyapranai, H Tsai, MCM Chen, S Sriyam, S Sinchaikul, et al. (2011) Glycoproteomic analysis and molecular modeling of haptoglobin multimers, Electrophoresis 32(12): 1422-1432.

58. R Saldova, MR Wormald, RA Dwek, PM Rudd (2008) Glycosylation changes on serum glycoproteins in ovarian cancer may contribute to disease pathogenesis. Dis Markers 25: 219-232.

59. N Okuyama, Y Ide, M Nakano, T Nakagawa, K Yamanaka, et al. (2006) Fucosylated haptoglobin is a novel marker for pancreatic cancer: A detailed analysis of the oligosaccharide structure and a possible mechanism for fucosylation. Int J Cancer 118(11): 2803-2808.

60. M Nakano, T Nakagawa, T Ito, T Kitada, T Hijioka, et al. (2008) Site-specific analysis of N-glycans on haptoglobin in sera of patients with pancreatic cancer: A novel approach for the development of tumor markers. Int J Cancer 122(10): 2301-2309.

61. Z Lin, DM Simeone, MA Anderson, RE Brand, X Xie, et al. (2011) Mass spectrometric assay for analysis of haptoglobin fucosylation in pancreatic cancer. J Proteome Res 10(5): 2602-2611. 
62. J Zhu, Z Lin, J Wu, H Yin, J Dai, Z. et al. (2014) Analysis of serum haptoglobin fucosylation in hepatocellular carcinoma and liver cirrhosis of different etiologies, J. Proteome Res. 13(6): 2986-2997.

63. H Asazawa, Y Kamada, Y Takeda, S Takamatsu, S Shinzaki, et al. (2015) Serum fucosylated haptoglobin in chronic liver diseases as a potential biomarker of hepatocellular carcinoma development. Clin Chem Lab Med 53(1): 95-102.

64. K Fujita, M Shimomura, M Uemura, W Nakata, M Sato, et al. (2014) Serum fucosylated haptoglobin as a novel prognostic biomarker predicting high-Gleason prostate cancer, Prostate 74(10): 1052-1058.

65. LF Hoagland 4th, MJ Campa, EB Gottlin, JE Herndon II, EF Patz Jr (2007) Haptoglobin and posttranslational glycan-modified derivatives as serum biomarkers for the diagnosis of nonsmall cell lung cancer. Cancer 110(10): 2260-2268.

66. JN Arnold, R Saldova, MC Galligan, TB Murphy, Y Mimura-Kimura, et al (2011) Novel glycan biomarkers for the detection of lung cancer. J Proteome Res 10(4): 1755-1764.
67. J Wu, J Zhu, H Yin, RJ Buckanovich, DM Lubman (2014) Analysis of glycan variation on glycoproteins from serum by the reverse lectin-based ELISA assay. J Proteome Res 13(4): 2197-2204.

68. Y Takeda, S Shinzaki, K Okudo, K Moriwaki, K Murata, et al. (2012) Fucosylated haptoglobin is a novel type of cancer biomarker linked to the prognosis after an operation in colorectal cancer. Cancer 118(12): 30363043

69. J Bones, JC Byrne, N O’Donoghue, C McManus, C Scaife, et al. (2011) Glycomic and glycoproteomic analysis of serum from patients with stomach cancer reveals potential markers arising from host defense response mechanisms. J Proteome Res 10: 1246-1265.

70. M Felder, A Kapur, J Gonzalez-Bosquet, S Horibata, J Heintz, et al. (2014) MUC16 (CA125): tumor biomarker to cancer therapy, a work in progress. Mol Cancer 13: 129

71. Y Kamada, N Kinoshita, Y Tsuchiya, K Kobayashi, H Fujii, et al. (2013) Reevaluation of a lectin antibody ELISA kit for measuring fucosylated haptoglobin in various conditions. Clin Chim Acta 417: 48-53. 